Research Article

\title{
IMPLEMENTATION OF POPULATION POLICY ON THE QUALITY OF DEATH CERTIFICATE ISSURANCE SERVICES
}

\author{
Deni Sudrajat ${ }^{1}$, Tine Badriatin ${ }^{2 *}$, Rudi Setiawan ${ }^{3}$, Sri Sudiarti 4 \\ 1 Program Studi Administrasi Negara, STIA YPPT - Priatim,Tasikmalaya 46182, Indonesia \\ ${ }^{2}$ Faculty of Economics and Business, University of Siliwangi, Tasikmalaya 46115, Indonesia \\ ${ }^{3}$ Program Studi Administrasi Niaga, STIA YPPT - Priatim, Tasikmalaya 46182, Indonesia \\ ${ }^{4}$ Politeknik Triguna, Tasikmalaya 46151, Indonesia
}

Article history:

Submission 07 June 2021

Revised 21 June 2021

Accepted 23 June 2021

*Corresponding author:

E-mail:

tinebadriatin@gmail.com

\begin{abstract}
This study aims to determine the influence of population administration policy implementation to service quality Issuance of a death certificate in the Department of Population and Civil Registration Tasikmalaya District, which is based on the theories that are relevant to the research conducted. The method used in this research is explanatory research, that is research based survey. Data collection techniques used through observation, documentation and questionnaires, while data analysis is used through multiple regression testing subsequent partial (lane) of each dimension studied (path analysis). From the results of the study showed that the implementation of a policy of population administration influence on the quality of service the issuance of a death certificate in the Department of Population and Civil Registration Tasikmalaya Regency is determined by the size and purpose of the policy, policy resources, characteristics or properties of entities implementing agencies, communication among relevant organizations with implementation activities, the attitude of the executive, and the environment as economic, social, political.
\end{abstract}

Keywords: Implementation of policies and quality of service

\section{Introduction}

The government in realizing good governance requires institutional reform and public management reform. Institutional reform involves revamping all local government tools, both in terms of structure and infrastructure. In addition to institutional reform and public sector management reform, to support the creation of good governance, one of which is related to the population administration management system, so that it becomes important because it is politically and economically related.

The government itself in regulating population problems has passed Law Number 23 of 2006 which has been changed to Law Number 24 of 2013 concerning Population Administration, which in order to improve Population Administration services in line with the demands of professional Population Administration services, meeting information technology

How to cite:

Sudrajat, D., Badriatin, T., Rudi Setiawan, R., \& Sudiarti S. (2021). Implementation of population policy on the quality of death certificate issurance services. Indonesian Journal of Social Science Research, 2(1), 33 - 38. 
standards , dynamic, orderly, and non-discriminatory in achieving minimum service standards towards excellent comprehensive services to overcome population problems.

Through the Law it is also stated that Population Administration is a series of structuring and controlling activities in the issuance of Population documents and Data through Population Registration, Civil Registration, Population Administration information management and the utilization of the results for public services and other sector development.

One of the things that get less attention in Population Administration is the administration of people who have died. The death of a citizen can be said as an important event, where in Law Number 24 of 2013 it is stated that Important Events are events experienced by a person including birth, death, stillbirth, marriage, divorce, child recognition, child ratification, child adoption, change of name and change of citizenship status.

The implementation of Population Administration in Tasikmalaya Regency is carried out by the Department of Population and Civil Registration. One of the tasks of the Department of Population and Civil Registration of Tasikmalaya Regency is to issue official documents related to an important event in population documents that have legal force as authentic evidence produced from the Population Registration and Civil Registration services.

In practice, the services provided by the Department of Population and Civil Registration of Tasikmalaya Regency related to the issuance of Death Certificates have not been running in accordance with public expectations, this is related to the implementation of Law Number 24 of 2013 concerning Population Administration by the Department of Population and Civil Registry. Tasikmalaya Regency.

The research conducted in this case is about the implementation of Law Number 24 of 2013 concerning Population Administration by the Department of Population and Civil Registry of Tasikmalaya Regency. According to Anderson in Wahab (2004) provides an understanding of policy by stating: "Policy is the behavior of a number of official actors, groups of government agencies or a series of actors in a particular field of activity".
While the definition of public policy according to Dunn (2003) by stating that:

Public policy is a complex pattern of interdependence of interdependent collective choices, including decisions not to act, made by government agencies or offices.

Government policies must be implemented properly, so that a policy can run according to its objectives. Winarno (2002) provides an understanding of policy implementation by stating the following:

Policy implementation is seen in a broad sense, as a legal administration tool where various factors, organizations, procedures, and techniques work together to carry out policies to achieve the desired impact or goal. Furthermore, Meter and Horn in Wahab (2004) state that policy implementation will be influenced by the following variables:

1. Policy size and purpose

2. Policy Resources

3. Characteristics or characteristics of the implementing agency

4. Communication between organizations related to implementation activities

5. Attitude of implementers

6. Environmental, social, political

Public policies that will be implemented by the government and have obtained legitimacy from the people's representative institutions, allow the government to act in the implementation of these policies. The implementation of public policies in the form of Laws or Regional Regulations is the implementation of explanatory public policies or is often said or termed as implementing regulations.

Public policy in its implementation must be useful for its target, in this case the community or the public. Policy implementation must of course be carried out through excellent service by the relevant organizational unit.

Goetsh and Davis in Tjiptono (2000), states that "Quality is a dynamic condition associated with products, services, people, processes, and the environment that meet or exceed expectations". Furthermore, Wyckop in Tjiptono (2000) states that "Service quality or service quality is the level of excellence expected and control over the level of excellence to meet customer desires". 
Parasuraman, Zeithaml, and Berry in Tjiptono (2005) state that measuring the quality of public services can be done through:

1. Tangibles (Physical Evidence), including physical facilities, equipment and supplies used, employee appearance, means of communication, cleanliness, tidiness and comfort.

2. Empathy (Empathy), including the ease of making good communication relationships, sincere personal attention and trying to understand consumer desires.

3. Reliability, namely the ability to provide services that are presented immediately, accurately and so on.

4. Responsiveness, namely the ability of employees to help customers and provide responsive service, employee alertness, employee speed in providing services, employee speed in handling transactions, handling consumer complaints and so on.

5. Assurance, includes knowledge, ability, courtesy, skills in providing information, friendliness of company employees.

\section{Method}

The research uses explanatory research methods, namely research based on surveys. The data obtained in the study were sourced from primary data and secondary data. Primary data is data obtained by researchers directly in the field, while secondary data is data obtained by researchers from existing sources, such as document data, records and regulations related to research. While the type of data in this study consists of qualitative data, namely data obtained in the form of information from agencies and other parties related to the problem to be discussed, and quantitative data, namely data obtained in the form of numbers that can be calculated.

Data collection techniques are used through observation, documentation and questionnaires, while data analysis is used through multiple regression which is then carried out partial testing (paths) of each dimension studied (path analysis). Respondents in this study were 36 employees at the Department of Population and Civil Registry of Tasikmalaya Regency, not including the Head of the Service.

\section{Result and Discussion}

The government in an effort to orderly Population Administration for citizens of the Republic of Indonesia has regulated it through Law Number 24 of 2013 concerning Amendments to Law Number 23 of 2006 concerning Population Administration which was made in the context of realizing orderly population administration nationally, the Unitary State of the Republic of Indonesia which Based on Pancasila and the 1945 Constitution of the Republic of Indonesia, it is essentially obligatory to provide protection and recognition of the determination of personal status and legal status for any Population Events and Important Events experienced by Residents and/or Indonesian Citizens who are outside the territory of the Unitary State. Republic of Indonesia.

Furthermore, the law was also made in the context of improving Population Administration services in line with the demands of professional Population Administration services, meeting information technology standards, dynamic, orderly, and non-discriminatory in achieving minimum service standards towards excellent comprehensive services to overcome population problems.

The Tasikmalaya Regency Government in carrying out the population administration of its citizens is carried out by the Population and Civil Registry Office as the main tasks and functions are regulated through the Tasikmalaya Regency Regional Regulation Number 15 of 2008 concerning the Tasikmalaya Regency Regional Office, while the details of the tasks of the Tasikmalaya Regency Population and Civil Registry Office have been regulated through Regulation of the Regent of Tasikmalaya Number 12 of 2012 concerning the Details of the Tasks of Units within the Department of Population and Civil Registration of the Regency of Tasikmalaya.

Every time a baby is born, the parents are required to make a birth certificate as well as if a family member dies, other family members are also required to make a death certificate. One of the purposes of making a death certificate is to prevent the data of the deceased from being misused by irresponsible parties. While the benefits of the Death Certificate include, among others, taking care of the determination 
of heirs, taking care of retired widows/widowers, managing insurance claims, and also the requirements to carry out remarriage for their spouses who have been abandoned.

The Population and Civil Registry Office of Tasikmalaya Regency in carrying out population administration as mandated by the law has not yet run smoothly, this is related to the policy information factor that has not yet reached the public, namely the importance of a Death Certificate for a family or community member in Tasikmalaya Regency. The issuance of a Death Certificate is one of the government policies related to population administration, where the service must be oriented to community satisfaction, so that the community can take care of their families or other communities in the issuance of Death Certificates.

Based on the results of data testing in finding the value of the influence between the implementation of population administration policies on the quality of service for issuing Death Certificates at the Population and Civil Registry Office of Tasikmalaya Regency, it is calculated through linear regression through a statistical program with the following results:



ANOVA ${ }^{b}$

\begin{tabular}{|ll|r|r|r|r|r|}
\hline Madel & & Sum of & df & Mean Square & F & Sig. \\
\hline 1 & Regression & 1537.187 & 6 & 256.198 & 10.538 & $.000=$ \\
& Residual & 705.035 & 29 & 24.312 & & \\
& Total & 2242.222 & 35 & & & \\
\hline
\end{tabular}

a. Predictors: (Constant), Lingkungan Ekonomi, sosial dan politik Sikap para pelaksana, Ukuran dan Tujuan Kebijkan, Komunikasi antar organisasi terkait, Ciri/sifat badan instansi, Sumber - sumber kebijakan

b. Dependent Variable: Kualitas Pelayanan

From the table model summary, it is known that the $\mathrm{R}$ square number is 0.686 , this shows that $68.6 \%$ of the quality of the Death Certificate issuance service at the Department of Population and Civil Registry of Tasikmalaya Regency can be explained by the implementation of population administration policies, while the rest $(100 \%-68.6 \%)=31.4 \%)$ explained by other causes (factors) that were not examined.

The effect of policy implementation on the quality of death certificate issuance services at the Department of Population and Civil Registry of Tasikmalaya Regency is tested through several factors that influence it, which include human resource factors where in the management of issuing Death Certificates at the Department of Population and Civil Registry of Tasikmaya Regency are quite available, plus participation from village officials in each region of Tasikmalaya Regency, however, costs are a separate problem for the community, especially for the underprivileged, as well as the processing time until the issuance of the Death Certificate is not as expected due to many factors, including the availability of board members family as well as the distance to the place of service for the issuance of a Death Certificate.

The ability of employees at the Department of Population and Civil Registry of Tasikmalaya Regency has been selected according to the education and work experience of the employees. The ability to work is very influential on the success of the organization, especially in providing services to the community. Every employee needs to have responsibility and discipline in carrying out their duties, so that the 
services provided can provide satisfaction to the community.

An important factor in implementing a government policy is communication, because without good communication, any good policy will not succeed in achieving the desired goal. Communication between employees implementing policies and communicating policies to the public is the key to the success of what is the goal of the policy. So every employee at the Department of Population and Civil Registry of Tasikmalaya Regency needs to understand and have the ability to communicate every policy that must be implemented by his organization.

The success of achieving the goals of the existence of a policy is very dependent on the at titude of the implementers of the policy, where every employee must have a sense of ownership and responsibility for his work duties. Achievements in population administration by the Department of Population and Civil Registry of Tasikmalaya Regency, in this case especially the issuance of Death Certificates, it is necessary for employees to make efforts to make it successful through pro-active involvement in the community by providing information about the importance of Death Certificates for families or someone who has died. .

Other factors in achieving the success of population administration policies through this research involve economic, social and political, economic, social and political environment. Of these problems, the most dominant are economic and social factors, firstly, the economic level in the rural area of Tasikmalaya Regency has not fully supported the policy due to the cost factor that must be borne and incurred by a family, then social values in the community that have not made a deed. Death as an important document.

From the results of testing and data analysis shows that the magnitude of the effect of the Implementation of Population Administration Policy on the Quality of Death Certificate issuance services at the Population and Civil Registry Office of Tasikmalaya Regency is determined by the size and objectives of the policy, policy sources, characteristics or nature of the implementing agency, communication between organizations related to implementation activities, the attitude of the implementers, and the economic, social, political environment.

Furthermore, in achieving the success of the implementation of population administration policies by the Department of Population and Civil Registry of Tasikmalaya Regency, the main key is the commitment of various parties, starting from policy implementers and the community themselves who must understand and understand the importance of Death Certificates for their families who have died.

\section{Conclusions}

Implementation of policies regarding population administration carried out by the Department of Population and Civil Registry of Tasikmalaya Regency through the size and objectives of the policy, policy sources, characteristics or characteristics of the implementing agency, communication between organizations related to implementation activities, the attitude of the implementers, and the economic environment, social and political activities have not been fully implemented optimally, which is shown by the large number of people who do not document their families who have died, which means that the objectives of the policy have not yet reached the community.

The services provided related to the issuance of Death Certificates by the Department of Population and Civil Registry of Tasikmalaya Regency still need to be improved so that they can provide excellent service to the community as service recipients. There is a need for service innovation so that population administration policies, especially for residents who have died, have their death certificates made by the person's family.

The conclusion of this study is that the implementation of population administration policies affects the quality of the issuance of Death Certificates at the Department of Population and Civil Registry of Tasikmalaya Regency is determined by the size and objectives of the policy, policy sources, characteristics or nature of the implementing agency, communication between organizations related to implementation activities, the attitude of the implementers, and the economic, social, political environment. 


\section{Reference:}

Arikunto, Suharsimi. 1999. Prosedur Penelitian: Suatu Pendekatan Praktek, Jakarta: Rineka Cipta.

Budiardjo Miriam dan Ibrahim Ambong, 2000. Fungsi Legislatif Dalam Sistem Politik Indonesia, Jakarta: RajaGrafindo Persada.

Davis, Keith dan Newstrom, 2000. Perilaku Dalam Organisasi, Edisi ketujuh, Penerbit. Erlangga, Jakarta.

Dunn, William N. 2003. Pengantar Analisis Kebijakan Publik, edisi kedua. Yogyakarta: Penerbit Gadjah Mada University Press.

Edward III, George C dan Ira Sharkansky, 2003. The Policy Predicament - Making and Implementing Public Policy, San Fransisco : W.H Freeman and Company.

Hoogerwerf, 1990. Ilmu Pemerintahan, Edisi terjemahan, Jakarta: Erlangga.

Islamy, Irfan, 2007. Prinsip-Prinsip Perumusan Kebijakan Negara, Jakarta: Bumi Aksara.

Kotler, Philip. 2000. Marketing Management, Edisi Milenium, International Edition. Prentice Hall. International, Inc, New Jersey.

Moenir. 2008. Manajemen Pelayanan Umum di Indonesia, Jakarta: PT. Bumi Aksara.

Muchsin dan Fadillah Putra, 2002. Hukum dan Kebijakan Publik, Jakarta: Averroes Press.

Nugroho, Rian, 2003. Kebijakan Publik, Jakarta: PT. Elex Media Komputindo.

Riant N, Dwidjowijoto,. 2003. Kebijakan Politik, Formulasi, Implementasi dan Evaluasi, Jakarta: PT. Elek Media Komputindo.

Sinambela, Lijan Poltak, dkk. 2007. Reformasi Pelayanan Publik: Teori, Kebijakan, dan Implementasi, Jakarta: PT Bumi Aksara.
Singarimbun, Masri dan Sofyan Effendi, 1995. Metodologi Penelitian, Jakarta; Gunung Agung.

Sirait, Alfonsus. 1991. Manajemen, Jakarta: Erlangga.

Subarsono, AG. 2005. Analisis Kebijakan Publik, Yogyakarta: Pustaka Pelajar.

Sugiyono, 2000. Metode Penelitian Bisnis, Bandung: Alfabeta.

Syafie, Kencana Inu, 2004. Birokrasi Pemerintahan Indonesia, Bandung, Mandar Maju.

Thoha Miftah, 1997. Pembinaan Organisasi; Proses Diagnosa dan Intervensi, Jakarta: PT.Raja Grafindo Persada.

Tjiptono, Fandy. 2004. Pemasaran Jasa, Malang: Bayu Media.

Triguno. 1997. Budaya Kerja, Menciptakan Lingkungan yang Kondusif untuk Meningkatkan Produktivitas Kerja, Jakarta: PT. Golden Teravon Press.

Wahab, Solichin Abdul, 2004. Analisis Kebijakan - Dari Formulasi ke Implementasi Kebijaksanaan Negara, Jakarta: Bumi Aksara.

Widodo, Joko. 2009. Analisis Kebijakan Publik, Jakarta: Bayumedia.

Winarno, Budi. 2002. Teori dan Proses Kebijakan Publik, Yogyakarta: Media Pressindo.

Another Document:

Undang-Undang Nomor 26 Tahun 2006 tentang Administrasi Kependudukan.

Keputusan Menteri Negara Pendayagunaan Aparatur Negara Nomor 81 Tahun 1993 tentang Pelayanan Prima.

Profil Dinas Kependudukan dan Catatan Sipil Kabupaten Tasikmalaya 